\title{
On the Oxidation of Different Iminic Bonds by Excess of 3-Chloroperbenzoic Acid
}

\author{
Luigino Troisi, ${ }^{* a}$ Marina M. Carrozzo, ${ }^{a}$ Cinzia Citti, ${ }^{a}$ Aurelia Falcicchio, ${ }^{\mathrm{b}}$ Rosmara Mansueto, ${ }^{\mathrm{a}}$ Francesca Rosato, ${ }^{\mathrm{a}}$ \\ Giuseppe Cannazza ${ }^{c}$ \\ a Dipartimento di Scienze e Tecnologie Biologiche ed Ambientali, Università del Salento, Via Prov. le Lecce-Monteroni, 73100 Lecce, Italy \\ Fax +39(0832)298732; E-mail: luigino.troisi@unisalento.it \\ b Istituto di Cristallografia (IC-CNR), Via Amendola 122/o, 70125 Bari, Italy \\ c Dipartimento di Scienze Farmaceutiche, Università degli Studi di Modena e Reggio Emilia, via Campi 183, 41125 Modena, Italy \\ Received: 19.10.2012; Accepted after revision: 15.11.2012
}

\begin{abstract}
In the present work the behavior of different substituted iminic bonds toward the oxidative action of 3-chloroperbenzoic acid is reported. The $\mathrm{C}=\mathrm{N}$ bond was or was not oxidized to oxaziridines, amides, oximes, nitroso-, nitro-, and azodioxy compounds depending on the substituents at the iminic group and on the imine/MCPBA stoichiometric ratio.
\end{abstract}

Key words: imines, oxidation, oxaziridines, $C$-nitroso compound, oximes

Although the reduction ${ }^{1}$ and hydrolysis ${ }^{2}$ of imines has been largely studied, only a few publications report its behavior toward oxidizing agents. It has been reported that benzylidene alkylamines lead to the corresponding oxaziridines by stoichiometric oxidation with peracids, ${ }^{3}$ urea hydrogen peroxide, ${ }^{4}$ and cobalt-mediated molecular oxygen $^{5}$ (Scheme 1).

$$
{ }_{A r}^{H}=N_{R}^{N} \stackrel{[O]}{\longrightarrow}{ }_{A r}^{H} Y_{N^{-}}
$$

$[O]=$ MCPBA, urea-hydrogen peroxide, $\mathrm{Co} / \mathrm{O}_{2}$

Scheme 1 Synthetic methodology for oxaziridine generation

A number of thermally stable oxaziridines, obtained by oxidation of benzylidene alkylamines, ${ }^{6}$ have been employed both as oxygenating and/or aminating agents of nucleophilic species ${ }^{7}$ and as reagents in cycloaddition reactions with heterocumulenes, ${ }^{8}$ alkenes, ${ }^{9}$ alkynes,,${ }^{10}$ and nitriles. ${ }^{11}$ Reports of reactions of imines with excess MCPBA are scarce. Previously, we have reported that the oxidation of benzylidene alkylamines $\mathbf{1}-\mathbf{3}$ by $1.1 \mathrm{mmol}$ of MCPBA in $\mathrm{CH}_{2} \mathrm{Cl}_{2}$ solution led to oxaziridines $\mathbf{1 a}-\mathbf{3 a}$ in good yields $(>90 \%),{ }^{12}$ while nitroso compounds $\mathbf{1 b}-\mathbf{3 b}$ rapidly dimerized to azodioxy compounds $\mathbf{1 c}-\mathbf{3 c}$ and were obtained employing $2.2 \mathrm{mmol}$ of MCPBA (Scheme 2). Furthermore compounds $\mathbf{2 b}, \mathbf{3 b}, \mathbf{2 c}$, and $\mathbf{3 c}$, having a hydrogen at the $\alpha$ position of $\mathrm{R}^{1}$, undergo isomerization into oximes $\mathbf{2 d}$ and $\mathbf{3 d}$ by heating in toluene solution.

SYNLETT 2013, 24, 0053-0056

Advanced online publication: 11.12.2012

DOI: 10.1055/s-0032-1317760; Art ID: ST-2012-D0903-L

(C) Georg Thieme Verlag Stuttgart · New York
Moreover, the azodioxy dimer $\mathbf{3 c}$ was obtained in quantitative yield by reaction of $1.1 \mathrm{mmol} \mathrm{MCPBA}$ with the isolated oxaziridine 3a.

The same result was obtained on oxidizing the cyclic imine 3,4-dihydro- $2 H$-pyrrole 4 with $1.1 \mathrm{mmol}$ of MCPBA; the condensed oxaziridine $4 \mathbf{a}$ (yield $98 \%$ ) was obtained in this case. Product 4a was subsequently oxidized into nitroso compound $\mathbf{4 b}$ that rapidly dimerized to azoxydimer $4 \mathbf{c}$ when a further $1.1 \mathrm{mmol}$ of MCPBA were added. Furthermore, on heating $\mathbf{4 c}$ in toluene $\left(80^{\circ} \mathrm{C}\right)$, $\mathbf{4 d}$ was obtained (yield 80\%, Scheme 3). ${ }^{12}$

Continuing our studies on the oxidation of imines with MCPBA we have discovered outcomes strongly dependent on the $\mathrm{C}=\mathrm{N}$ bond substituents. Due to the lower basicity of the nitrogen in 5-7 with respect to compounds $\mathbf{1 - 4}$, the second oxygen transfer on oxaziridines $5 \mathbf{a}-7 \mathbf{a}$, formed on initial oxidation, did not take place. Instead, $\mathrm{N}, \mathrm{N}$-diarylamides 8-10 were obtained both with $1.1 \mathrm{mmol}$ or $2.2 \mathrm{mmol}$ of peracid, after a carbon-nitrogen migration of the aryl group (Scheme 4). Amides were also obtained in reactions of imines with sodium perborate ${ }^{13}$ or with $\mathrm{MCPBA}$ and $\mathrm{BF}_{3} \cdot \mathrm{OEt}_{2} \cdot{ }^{14}$

A further decrease of basicity of the imine nitrogen as in oximes 11, isoxazolines 12 , benzothiadiazines 13 , and osazones 14 (Figure 1), due to the presence of a heteroatom on the nitrogen atom, diminished the reactivity towards $\mathrm{C}=\mathrm{N}$ oxidation, and starting materials were recovered even using $5.0 \mathrm{mmol}$ of MCPBA. Instead the osa-<smiles>O/N=C(/P)c1ccccc1</smiles><smiles>BrC1CC(C2=NOC(Br)C2)=NO1</smiles>

11a: $R=H$

11b: $R=M e$

12a: $\mathrm{Ar}=4$-tolyl 12b: $\mathrm{Ar}=1$-naphthyl<smiles>[R]C1=N[SH+]([O-])c2cc(Cl)ccc2N1P</smiles><smiles>C/C(=N\N(C)C)c1ccccc1</smiles>

13a: $R^{1}=\mathrm{H} ; \mathrm{R}^{2}=\mathrm{Me}$ 13b: $R^{1}, R^{2}=\left(\mathrm{CH}_{2}\right)_{3}$

14

Figure 1 
Scheme 2 Oxidative action of the MCPBA toward $N$-alkyl imines

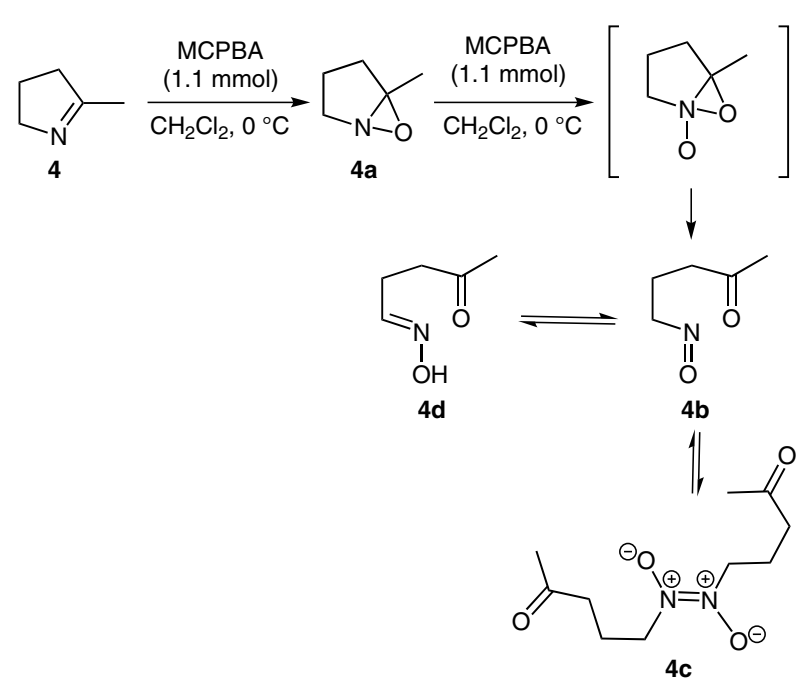

Scheme 3 Oxidative action of MCPBA toward cyclic imines

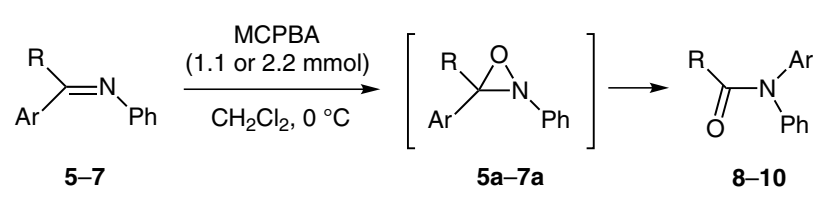

5, 8: $\mathrm{R}=\mathrm{H}, \mathrm{Ar}=\mathrm{Ph}$

6, 9: $\mathrm{R}=\mathrm{H}, \mathrm{Ar}=4-\mathrm{ClC}_{6} \mathrm{H}_{4}$

7, 10: $\mathrm{R}=\mathrm{Me}, \mathrm{Ar}=\mathrm{C}_{6} \mathrm{H}_{5}$

Scheme 4 Oxidative action of MCPBA toward aryl imines

zone 14 was oxidized on the amine nitrogen, leading to a mixture of different products. ${ }^{15}$

On the contrary, imines containing a heteroatom at the imine carbon showed high reactivity towards oxidation. Oxazolines 15 reacted with $1.1 \mathrm{mmol}$ of peracid leading to the stable oxaziridines $\mathbf{1 5}$ after five hours. Further addition of $1.1 \mathrm{mmol}$ of peracid to $\mathbf{1 5 a}$ led to an unstable $N$ oxide intermediate which converted into $\mathbf{1 5 b}$ in equilibrium with the dimeric compound 15c (yield 98\%) and/or oxime $15 d(R=H$, Scheme 5$) .{ }^{12}$
Other heterocycles with similar structure exhibit the same behavior. When 16 was treated with $2.2 \mathrm{mmol}$ of peracid, 16b was formed, which converted into the azoxydimeric form 16c (yield 98\%, ${ }^{16}$ Scheme 6). These results indicate that the oxygen bound to the iminic carbon atom increases reactivity toward oxidation reaction.

Imidazoline 17, which contains a nitrogen atom connected to the imine carbon was transformed (50\%) into nitroso compound $\mathbf{1 7 b}$ and subsequently into azoxydimer $\mathbf{1 7 c}$ when treated with $1.1 \mathrm{mmol}$ of MCPBA. It was not possible to isolate oxaziridine 17a and the intermediate form of the second oxidation because of their high reactivity. Instead, 17 led to $\mathbf{1 7 c}$ (yield 99\%) when treated with 2.2 mmol of peracid (Scheme 7).

Only a $50 \%$ conversion of $2 H$-1,2,4-benzothiadiazine derivatives 18 and $19,{ }^{17}$ structurally similar to the imidazolines, into nitroso compounds $\mathbf{1 8 b}-\mathbf{1 9 b}$ was observed on reacting with $1.1 \mathrm{mmol}$ of MCPBA, with azoxydimers $18 \mathrm{c}$ and 19c being isolated as final products. On the other hand, when $2.2 \mathrm{mmol}$ of peracid were employed the transformation to the azoxydimers was complete (99\%, Scheme 8).

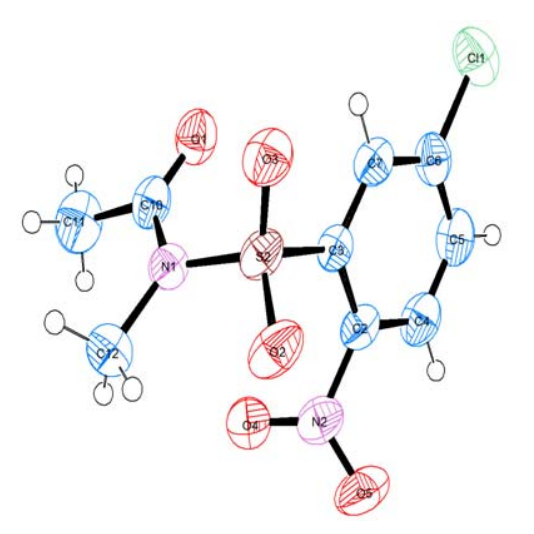

Figure 2 Projection of compound 18e at $298 \mathrm{~K}$ 


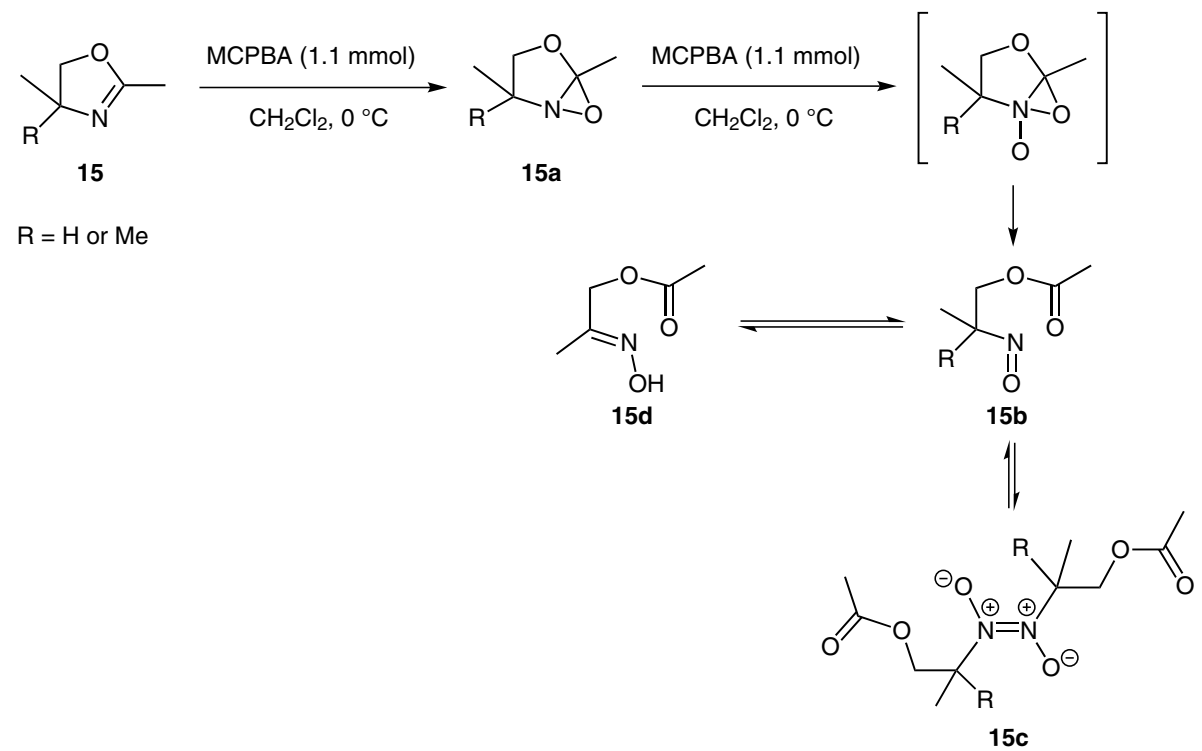

Scheme 5 Oxidative action of the MCPBA toward O-activated cyclic imines

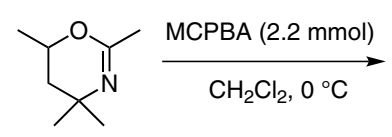

16<smiles>CC(=O)OC(C)C(C)N=O</smiles>

$16 b$

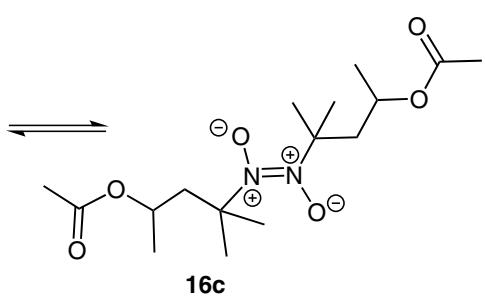

$16 c$

Scheme 6 Oxidative action of the MCPBA toward O-activated cyclic imines

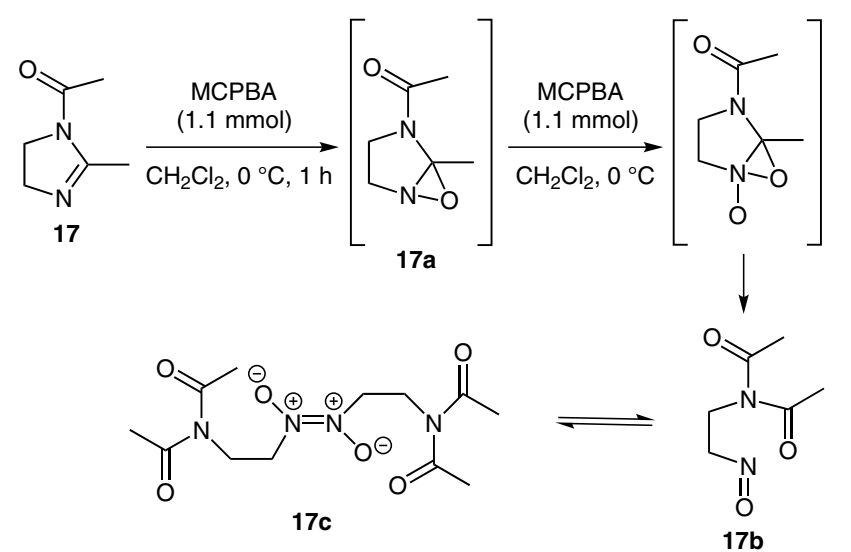

Scheme 7 Oxidative action of the MCPBA toward N-activated cyclic imines

Furthermore, nitro compound $\mathbf{1 8 e}$ (90\% yield) was isolated on treatment of 18 with $5.5 \mathrm{mmol}$ of MCPBA. The structure of $18 \mathrm{e}$ was characterized by X-ray crystallographic analysis (Figure 2). ${ }^{18}$

In summary, in this work we have examined the influence of substituents on the behavior of imines towards MCPBA. Oxygen, nitrogen, or sulfur, attached to the nitrogen, render the substrates resistant to oxidation of the $\pi$-bond. On the contrary, a heteroatom or carbon substitu- ent on the imine carbon make the imine double bond more reactive; oxaziridines, amides, oximes, nitroso-, nitro-, and azoxy compounds can be synthesized depending on the imine/MCPBA stoichiometric ratio.

\section{General Procedure}

An excess of MCPBA ( 1.1 or $2.2 \mathrm{mmol})$ in $\mathrm{CH}_{2} \mathrm{Cl}_{2}(3 \mathrm{~mL})$ was added to a solution of the requisite imine $(1.0 \mathrm{mmol})$, dissolved in $\mathrm{CH}_{2} \mathrm{Cl}_{2}(5 \mathrm{~mL})$, with stirring and cooling $\left(0-5{ }^{\circ} \mathrm{C}\right)$. When reaction was complete (5-6 h), the excess of $m$-chloroperbenzoic acid, and the benzoic acid formed was removed by filtration. The filtrate was washed twice with a dilute solution of $\mathrm{Na}_{2} \mathrm{SO}_{3}(5 \%)$, then with a solution of $\mathrm{Na}_{2} \mathrm{CO}_{3}(5 \%)$, and finally with $\mathrm{H}_{2} \mathrm{O}$. After drying over anhyd $\mathrm{MgSO}_{4}$, the mixture was concentrated in vacuo, and the crude product was purified by column chromatography (silica gel partly deactivated with $\mathrm{Et}_{3} \mathrm{~N}$ ).

\section{Acknowledgment}

Thanks are due to the University of Salento and C.I.N.M.P.I.S. (Consorzio Interuniversitario Nazionale Metodologie e Processi Innovativi di Sintesi) for financial support. We would also like to thank Giuseppe Chita (Istituto di Cristallografia (IC-CNR), Via Amendola 122/o, 70125, Bari, Italy) for X-ray interpretation.

Supporting Information for this article is available online at http://www.thieme-connect.com/ejournals/toc/synlett. 


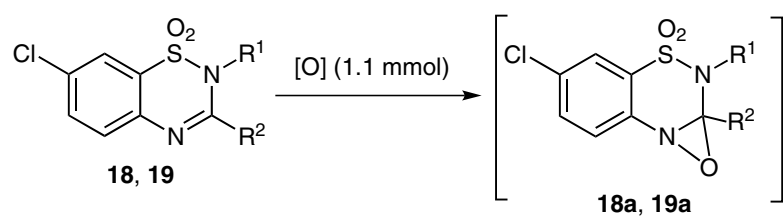

18: $R^{1}=R^{2}=M e$ 19: $R^{1}-R^{2}=\left(\mathrm{CH}_{2}\right)_{3}$<smiles></smiles>

$18 b, 19 b$<smiles>C1=CC=C1</smiles>

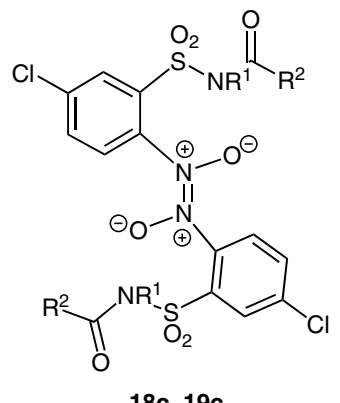

Scheme 8 Oxidative action of the MCPBA toward S-activated cyclic imines

\section{References and Notes}

(1) (a) For a review, see: Harada, T. In The Chemistry of the Carbon-Nitrogen Double Bond; Patai, S., Ed.; Interscience: New York, 1970, 276-293. (b) Rylander, P. N. Best Synthetic Methods: Hydrogenation Methods; Academic Press: London, 1985, 193.

(2) Ranu, B. C.; Sarkar, D. C. J. Org. Chem. 1988, 53, 878

(3) (a) Widmer, J.; Keller-Schierlein, W. Helv. Chem. Acta 1974, 57, 657. (b) Emmons, W. D. J. Am. Chem. Soc. 1956, 78,6208 .

(4) Lin, Y.; Miller, M. J. J. Org. Chem. 2001, 66, 8282.

(5) Damavandi, J. A.; Karami, B.; Zolfigol, M. A. Synlett 2002, 933.

(6) Troisi, L.; Rosato, F. Encyclopedia of Reagents for Organic Synthesis; John Wiley and Sons: New York, 2011,; DOI: 10.1002/047084289X.rn01335.

(7) Blanc, S.; Bordogna, C. A. C.; Buckley, B. R.; Elsegood, M. R. J.; Bulman Page, P. C. Eur. J. Org. Chem. 2010, 882; and references cited therein.

(8) Davis, F. A.; Wei, J.; Sheppard, A. C.; Gubernick, S. Tetrahedron Lett. 1987, 28, 5115.

(9) Fabio, M.; Ronzini, L.; Troisi, L. Tetrahedron 2007, 63, 12896.

(10) Fabio, M.; Ronzini, L.; Troisi, L. Tetrahedron 2008, 64, 4979.

(11) Troisi, L.; Ronzini, L.; Rosato, F.; Videtta, V. Synlett 2009, 1806.

(12) Perrone, S.; Pilati, T.; Rosato, F.; Salomone, A.; Videtta, V.; Troisi, L. Tetrahedron 2011, 67, 2090.

(13) Nongkunsarn, P.; Ramsden, C. A. Tetrahedron 1997, 53, 3805.

(14) An, G.; Kim, M.; Kim, J. Y.; Rhee, H. Tetrahedron Lett. 2003, 44, 2183.

(15) (a) Gillis, B. T.; LaMontagne, M. P. J. Org. Chem. 1967, 32 , 3318. (b) Witkop, B.; Kissman, H. M. J. Am. Chem. Soc. 1953, 75, 1975. (c) Lynch, B. M.; Pausacker, K. H. J. Chem. Soc. 1953, 2517.

(16) Compound 16c: total yield 98\%, $179.4 \mathrm{mg}$; $E$-Isomer: yield $89.7 \mathrm{mg}, 49 \%$, oil; $R_{f}=0.33(\mathrm{PE}-\mathrm{EtOAc}=$ 9:1). ${ }^{1} \mathrm{H}$ NMR $\left(400.13 \mathrm{MHz}, \mathrm{CDCl}_{3}\right): \delta=1.23(3 \mathrm{H}, \mathrm{d}, J=$ $\left.6.5 \mathrm{~Hz}, \mathrm{CHCH}_{3}\right), 1.57\left(3 \mathrm{H}, \mathrm{s}, \mathrm{CCH}_{3}\right), 1.59\left(3 \mathrm{H}, \mathrm{s}, \mathrm{CCH}_{3}\right)$, $1.96\left(3 \mathrm{H}, \mathrm{s}, \mathrm{COCH}_{3}\right), 1.97-2.07\left(1 \mathrm{H}, \mathrm{m}, \mathrm{CH}_{\mathrm{a}} \mathrm{H}_{\mathrm{b}} \mathrm{CH}\right), 2.47$ $2.53\left(1 \mathrm{H}, \mathrm{m}, \mathrm{CH}_{\mathrm{a}} \mathrm{H}_{\mathrm{b}} \mathrm{CH}\right), 5.02-5.10\left(1 \mathrm{H}, \mathrm{m}, \mathrm{CHCH}_{3}\right) .{ }^{13} \mathrm{C}$ $\operatorname{NMR}\left(100.62 \mathrm{MHz}, \mathrm{CDCl}_{3}\right): \delta=20.8,24.5,27.6,45.7,66.8$,
86.1, 170.3. FTIR $\left(\mathrm{CHCl}_{3}\right): 2948,2845,1730,(\mathrm{C}=\mathrm{O}), 1270$, (NO), $1080 \mathrm{~cm}^{-1}$. ESI-HRMS: $m / z$ calcd for $\mathrm{C}_{17} \mathrm{H}_{33} \mathrm{~N}_{2} \mathrm{O}_{6}[\mathrm{M}$ $+\mathrm{H}]^{+}:$361.2333; found: 361.2330 .

Z-Isomer: yield $89.7 \mathrm{mg}, 49 \%$, oil. ${ }^{1} \mathrm{H}$ NMR $(400.13 \mathrm{MHz}$, $\left.\mathrm{CDCl}_{3}\right): \delta=1.04\left(3 \mathrm{H}, \mathrm{s}, \mathrm{CCH}_{3}\right), 1.14\left(3 \mathrm{H}, \mathrm{s}, \mathrm{CCH}_{3}\right), 1.20$ $\left(3 \mathrm{H}, \mathrm{d}, J=6.1 \mathrm{~Hz}, \mathrm{CHCH}_{3}\right), 1.86\left(3 \mathrm{H}, \mathrm{s}, \mathrm{COCH}_{3}\right), 2.15(1$ $\left.\mathrm{H}, \mathrm{dd}, J=15.3,3.1 \mathrm{~Hz}, \mathrm{CH}_{\mathrm{a}} \mathrm{H}_{\mathrm{b}} \mathrm{CH}\right), 2.78(1 \mathrm{H}, \mathrm{dd}, J=15.3$, $\left.9.7 \mathrm{~Hz}, \mathrm{CH}_{\mathrm{a}} \mathrm{H}_{\mathrm{b}} \mathrm{CH}\right), 4.84-4.92\left(1 \mathrm{H}, \mathrm{m}, \mathrm{CH}_{\mathrm{a}} \mathrm{H}_{\mathrm{b}} \mathrm{CH}\right) .{ }^{13} \mathrm{C}$ $\operatorname{NMR}\left(100.62 \mathrm{MHz}, \mathrm{CDCl}_{3}\right): \delta=20.5,21.2,21.9,43.2,67.3$, 97.9, 170.5. FTIR $\left(\mathrm{CHCl}_{3}\right): 2950,2845,1735,(\mathrm{C}=\mathrm{O}), 1270$, (NO), $1080 \mathrm{~cm}^{-1}$. ESI-HRMS: $m / z$ calcd for $\mathrm{C}_{17} \mathrm{H}_{33} \mathrm{~N}_{2} \mathrm{O}_{6}[\mathrm{M}$ $+\mathrm{H}]^{+}:$361.2333; found: 361.2330 .

(17) Carrozzo, M. M.; Battisti, U. M.; Cannazza, G.; Citti, C.; Parenti, C.; Troisi, L. Tetrahedron Lett. 2012, 53, 3023.

(18) (a) Crystal Data for Compound 18e $\mathrm{C}_{9} \mathrm{H}_{9} \mathrm{Cl}_{1} \mathrm{~N}_{2} \mathrm{O}_{5} \mathrm{~S}_{1}, F w=292.69, T=298 \mathrm{~K}$, monoclinic, space group $P 2_{1} / n, a=11.983(13), b=7.370(6), c=15.357(12) \AA$, $\alpha=90, \beta=113.89(5), \gamma=90, V=1240.0 \AA^{3}, Z=4, \mu$ (Mo $\mathrm{K} \alpha)=0.491 \mathrm{~mm}^{-1}$; crystal dimensions $0.3 \times 0.2 \times 0.06 \mathrm{~mm}$. The X-ray experiments were carried out at r.t. by a BrukerNonius KappaCCD diffractometer, using Mo K $\alpha$ radiation $(\lambda=0.71073 \AA)$. Data collection was performed by COLLECT (Nonius, 2002. COLLECT and EVAL. Nonius $\mathrm{BV}$, Delft, The Netherlands), cell refinement by DIRAX ${ }^{18 \mathrm{~b}}$ and data reduction by EVAL (Nonius, 2002. COLLECT and EVAL. Nonius BV, Delft, The Netherlands). Absorption effects were corrected by $S A D A B S .{ }^{18 c}$ The crystal structure was solved by SIR $2011^{18 \mathrm{~d}}$ and refined by SHELXL-97. ${ }^{18 \mathrm{e}}$ The $\mathrm{H}$ atoms were placed at calculated positions and refined according to a riding model approximation. The software used for preparing the material for publication: $\operatorname{Win} G X ;{ }^{18 f}$ the software used for molecular graphics: Ortep $-3 .{ }^{18 \mathrm{~g}}$ Detailed crystallographic data were deposited as CCDC 884506 with the Cambridge Crystallographic Data Centre, 12 Union Road, Cambridge CB2 1EZ, UK. (b) Duisenberg, A. J. M. J. Appl. Crystallogr. 1992, 25, 92. (c) Sheldrick, G. M. SADABS; University of Göttingen: Germany, 2002. (d) Burla, M. C.; Caliandro, R.; Camalli, M.; Carrozzini, B.; Cascarano, G. L.; De Caro, L.; Giacovazzo, C.; Polidori, G.; Siliqi, D.; Spagna, R. J. Appl. Crystallogr. 2007, 40, 609; the updated version of SIR2008 . (e) Sheldrick, G. M. Acta Crystallogr., Sect. A: Found. Crystallogr. 2008, A64, 112. (f) Farrugia, L. J. J. Appl. Crystallogr. 1999, 32, 837. (g) Farrugia, L. J. J. Appl. Crystallogr. 1997, 30, 565. 